\title{
Ethnic differences in pediatric SLE early disease severity: a comparison between Hispanic- Americans and European-Americans
}

\author{
Peony Liu², Jennifer MP Woo², Miriam F Parsa', Gil Amarilyo², Deborah K McCurdy², Ornella J Rullo² \\ From 2011 Pediatric Rheumatology Symposium sponsored by the American College of Rheumatology \\ Miami, FL, USA. 2-5 June 2011
}

\section{Purpose}

Systemic lupus erythematosus (SLE) is an autoimmune disease with higher incidence and increased disease severity, including increased medication requirements and morbidity, in people not uniquely of European descent. Few studies explore the differences between ethnic groups at presentation and early in the disease process, and no studies exist to our knowledge specifically evaluating the pediatric Hispanic population. We hypothesize, based on clinical experience, that pediatric SLE patients of Hispanic descent have an earlier, more severe disease course compared to patients of European descent.

\section{Methods \\ We retrospectively reviewed the charts of 43 patients with diagnosis of SLE prior to age 18 (pSLE; mean age at diag- nosis 12.9 years; 37 females) currently followed at the pediatric rheumatology clinic of an urban tertiary-care center. ACR criteria at diagnosis and any renal biopsy results were documented. All progress notes within 12 months after diagnosis were evaluated for cumulative steroid use score $(0:<150 \mathrm{mg} / \mathrm{kg} ; 1: 150-300 \mathrm{mg} / \mathrm{kg}$; 2: $>300 \mathrm{mg} / \mathrm{kg}$ ), additional immunosuppressant require- ments, and urine protein-creatinine ratios at six month intervals. Comparison between Hispanic-American and European-American pSLE for these data was conducted using computed means, 95\% confidence intervals, Student's one-tailed t-test, and Fisher's exact test. We are expanding this study to completely evaluate the experience at our center by including all HA and EA pSLE followed for the previous 10 years.}

${ }^{2}$ UCLA, Los Angeles, CA, USA

Full list of author information is available at the end of the article

\section{Results}

Hispanic-American (HA) pSLE patients $(\mathrm{n}=36)$ were diagnosed at a younger age than European-American (EA) patients $(\mathrm{n}=7)$, with a mean age at diagnosis of 12.5 compared to 15 years $(\mathrm{p}=0.05)$. HA pSLE patients presented with more ACR criteria within 6 months of diagnosis compared to EA (4.5 vs. $3.5 ; \mathrm{p}=0.04)$. On average, more HA patients presented with nonerosive arthritis $(\mathrm{p}=0.02)$ and photosensitivity $(\mathrm{p}=0.07)$; they also trended toward increased rates of discoid rash $(\mathrm{p}=0.18)$ and abnormal urine protein-creatinine ratios $(92 \%$ vs. $67 \% ; \mathrm{p}=0.13$ ), although there was no statistical difference in the absolute rate of lupus nephritis at disease onset ( $\mathrm{p}=0.35)$. Further, HA pSLE required more cumulative steroids by one year post-diagnosis, receiving a cumulative prednisone score of " 2 " more frequently $(19.4 \%$ vs. $0.0 \%$; p < 0.0001$)$ than did EA. Of all pSLE requiring $>150 \mathrm{mg} / \mathrm{kg}$ cumulative steroids by one year post-diagnosis, HA received an increased number of additional immunosuppressants ( 3.2 versus $2 ; \mathrm{p}=0.04$ ).

\section{Conclusion}

HA pediatric patients were diagnosed with SLE at a younger age, with more ACR criteria and higher urine protein-creatinine ratios. Concurrent trends of higher steroid and immunosuppressant requirement within the first year post-diagnosis suggest that differences exist early in the disease course of HA compared with EA pSLE.

\section{Disclosure}

Peony Liu: None; Jennifer M.P. Woo: None; Miriam F. Parsa: None; Gil Amarilyo: None; Deborah K. McCurdy: None; Ornella J. Rullo: None.
Ciomed Central

C 2012 Liu et al; licensee BioMed Central Ltd. This is an Open Access article distributed under the terms of the Creative Commons Attribution License (http://creativecommons.org/licenses/by/2.0), which permits unrestricted use, distribution, and reproduction in any medium, provided the original work is properly cited. 


\section{Author details}

${ }^{1}$ UCLA, Manhattan Beach, CA, USA. ${ }^{2}$ UCLA, Los Angeles, CA, USA.

Published: 13 July 2012

doi:10.1186/1546-0096-10-S1-A21

Cite this article as: Liu et al.: Ethnic differences in pediatric SLE early

disease severity: a comparison between Hispanic-Americans and

European-Americans. Pediatric Rheumatology 2012 10(Suppl 1):A21.

Submit your next manuscript to BioMed Central and take full advantage of:

- Convenient online submission

- Thorough peer review

- No space constraints or color figure charges

- Immediate publication on acceptance

- Inclusion in PubMed, CAS, Scopus and Google Scholar

- Research which is freely available for redistribution

Submit your manuscript at 